\title{
Evaluation of Results from an Investigation of the Timber Casing of an Underground Cistern in Tepenec Castle
}

\author{
Vendula Vránováa ${ }^{a}$ Michal Rybníček ${ }^{b}$, Tomáš Koláŕr \\ a Archaeological Centre Olomouc, subsidised organisation, U Hradiska 42/6, 77900 Olomouc, Czech Republic \\ ${ }^{b}$ Department of Wood Science, Faculty of Forestry and Wood Technology, Mendel University in Brno, Zemědělská 3 , 61300 Brno, Czech Republic
}

\section{ARTICLE INFO}

\section{Article history:}

Received: 8 November 2010

Accepted: 11 February 2011

Keywords:

archaeology

dendrochronology

cistern

medieval castle

Moravia

\begin{abstract}
This article describes an archaeological and dendrochronological research of a cistern discovered during the archaeological rescue excavations in the bailey of a medieval castle ruin at Tepenec, Central Moravia in 2008. The article characterizes the Tepenec site, describes the form of cistern, the archaeological research methodology as well as the methodology of dendrological analysis. The conclusion is devoted to the analysis of the dendrological dating results and how they benefit and expand our knowledge of the archaeology of the site.
\end{abstract}

\section{Introduction}

Excavations on a promontory with the remains of a Late Bronze Age hillfort and $14^{\text {th }}$ century Tepenec Castle have been in progress for many years, as the hill has seen gradually diminishing commercial exploitation since the end of 1960s (Vránová, Vrána 2005, here also the cumulative literature on Tepenec; Vránová 2008; 2009). Just under roughly half the hill has been removed (the inner ward of the castle and part of the bailey are already missing). As a result several excavation campaigns from 1997-1999 and 2007-2008 (Figure 1) have concentrated in the area of the bailey. During the most recent excavation in 2008 a cistern was also discovered and examined. The results of this investigation, which have contributed significantly to our knowledge of the locality, are the subject of this article.

The locality of Tepenec Castle lies on the border of the Lower Jeseníky Mountains, near the village of Jívová, about $15 \mathrm{~km}$ northeast of Olomouc. The promontory has an elevation of 480-519 $\mathrm{m}$ above the valley floor, through which flows Bělkovický creek (Figure 2).

${ }^{*}$ Corresponding author. E-mail: vranova@ac-olomouc.cz
The castle (originally called Twingenberg) was founded in 1340 by Charles IV, then Margrave of Moravia, for better protection and control over the "Jivovská" road. The castle was not long utilised. Tepenec was conquered twice during the war between the Moravian Margrave brothers' Jobst and Procopius, initially in 1381 and again around 1400 . The castle was not kept in usable condition afterwards. Indisputable proof of the conquest of the castle is found in the Olomouc Land Registry in an entry from 9 January 1406, which describes Tepenec Castle as a ruin. In 1405 Margrave Jobst gave Tepenec to the Carthusian Order from Dolany, who owned it as late as their dissolution in 1782 (for detailed sources on the history of the castle see Burian 1979). Archaeological excavations have not yielded any evidence testifying to any significant activity at this site during Carthusian ownership. Only a minimum of ceramics and other finds were discovered which can be dated after the $14^{\text {th }}$ century.

\section{Methodology}

The rescue archaeological methodology at the Tepenec site is always based on the division of the research space into a grid of $5 \times 5 \mathrm{~m}$ squares. In the last 5 stages the squares were 


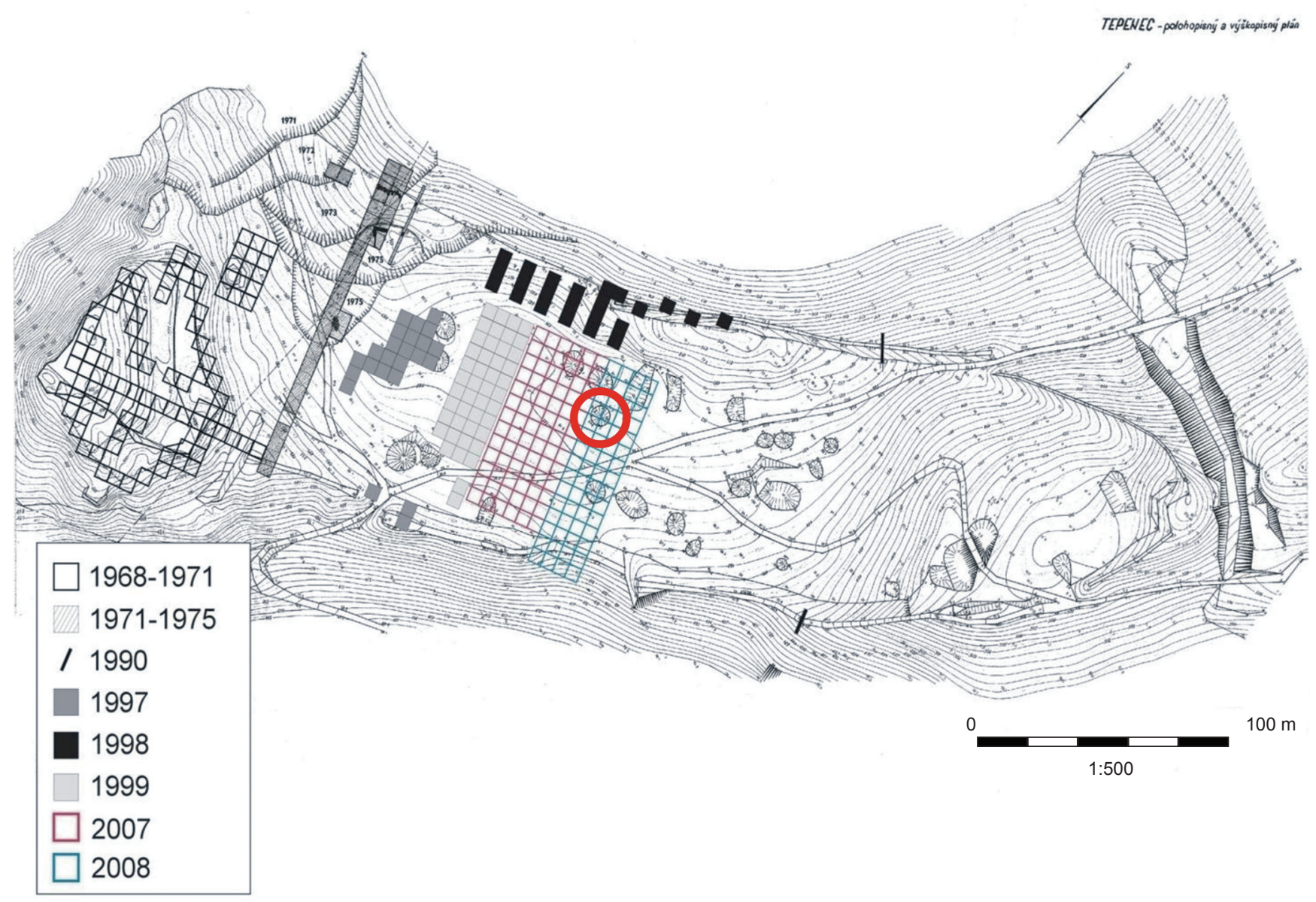

Figure 1. Map of the locality Jivová - Tepenec with marked excavation areas; position of the cistern is marked with a red circle. Map by P. Grenar.

investigated the chessboard way, due to time constraints (Kalábek, Tymonová 1998; 1999; Procházková 2001, Vránová, Vrána 2005; Vránová 2008; 2009). In any particular squares a cultural layer was examined at c. $20 \mathrm{~cm}$ intervals. Archaeological features embedded either in the cultural layer or in the bedrock were examined in natural layers. In 2008, the investigated area covered $75 \times 20 \mathrm{~m}$ and was divided into 60 squares. This year we focused first on the excavation of 4 visible depressions, because we assumed from the previous experience that relics of medieval construction would be found in these locations. Our research revealed that 3 of these depressions are relics of the medieval buildings, strictly speaking their cellars, and the fourth one was the cistern. The cistern was examined through the layers of its infill. Wood samples and samples for archaeobotanical analysis were taken from the layers.

The cistern, situated roughly in the middle of the bailey, served as a water reservoir, gathering both ground-water discharge and rain water. Its upper part is funnel-shaped, tapering inwards an average of ca $5 \mathrm{~m}$ for every 3 metres of depth. The overall depth of the cistern is $6.8 \mathrm{~m}$. At a depth of $4.5 \mathrm{~m}$, a $2.2 \mathrm{~m}$ deep wooden rectangular casing composed of round and semi-round wooden beams was set into the round pit (Figure 3). The bottom of the cistern was paved with large flat stones (Figure 4). The casing is preserved in very good condition thanks to a permanently wet environment, which was maintained by soaking during the excavations. The cistern contained a grey boggy fill, the upper part of which (above the casing) contained a large amount of rubble, probably from the collapsed wall lining. In the lower part there were many pieces of wood, most probably from the aboveground roofing construction. At this level we discovered the wooden shaft of a well winch, amongst other finds.

It is interesting that in an area of up to several metres around the cistern bedrock outcrops rise to about $2.5 \mathrm{~m}$ below the present surface level, with the cistern recessed into ground composed of weathered rock. The people who built the cistern evidently used a natural crack in the rock. The infill of the cistern contains a relatively large amount of 14th century pottery and iron slag. Several glass fragments from a medieval goblet were also found. Based on these finds and the fact that the castle was reported to be deserted since the early $15^{\text {th }}$ century, we supposed that the cistern was medieval. A dendrochronological analysis was carried out to establish a more precise dating of the emergence and determine the wood species from which the casing was built. Wood samples from the wall lining of the underground cistern and from its infill were taken with a Pressler borer, or by sawing 
Figure 2. Position of the locality Jivová - Tepenec on the basic map of the Czech Republic 1:10 000. Map by P. Grenar.

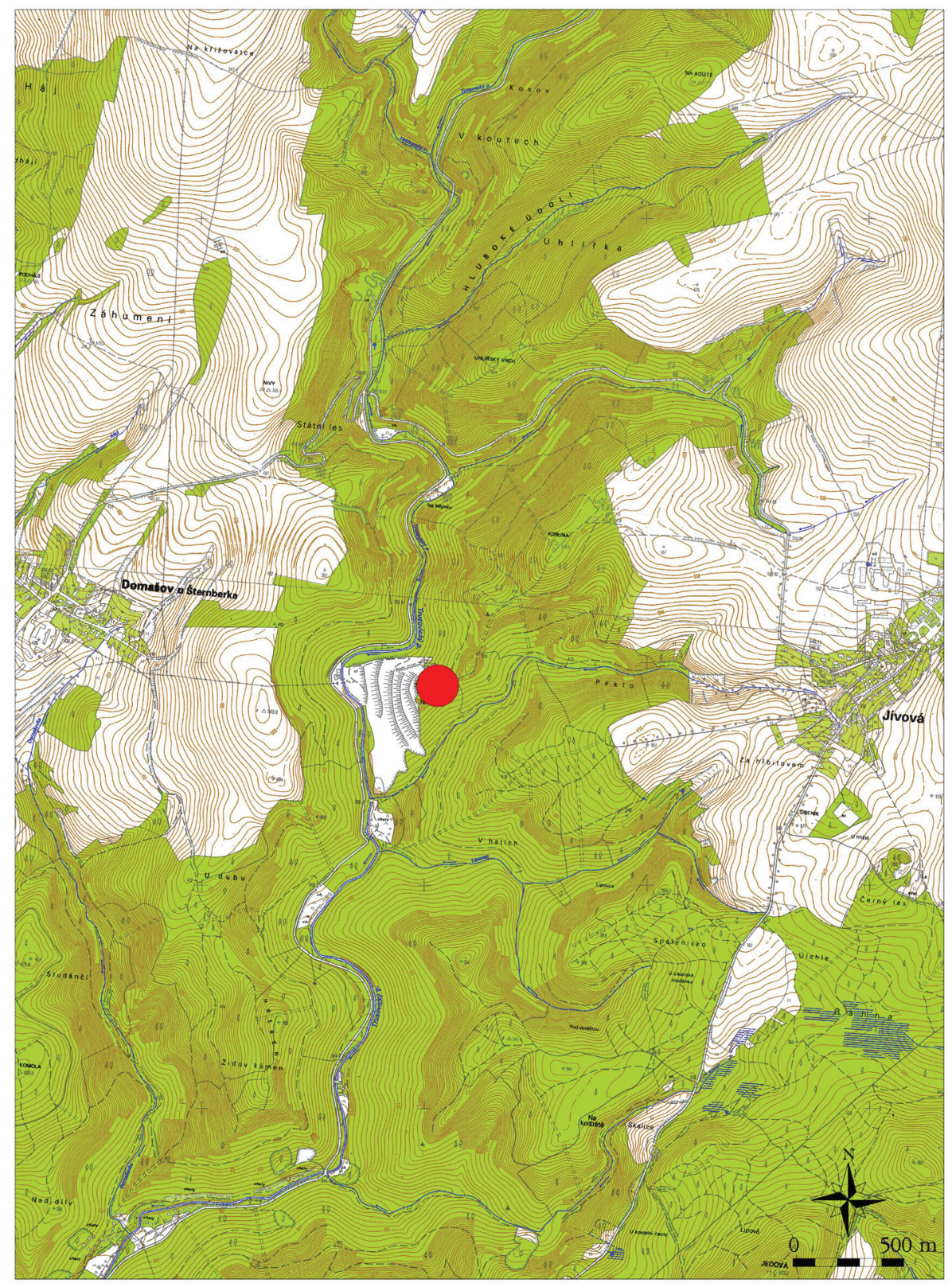

off transversal disks. The samples were processed using the standard dendrochronological methods (Cook, Kairiukstis 1990, Rybníček 2004).

The sequences of annual rings were measured in all samples. Three average tree-ring curves were elaborated, and dated according to the Czech fir - Jedle ČR 2005 (Vinař et al. 2005), Moravian fir - Jedle Morava 2005 (Vinař et al. 2005) and Moravian oak - Morges 2005 (Rybníček 2010): standard chronologies to 1548 . Since no separate elm tree chronology is available for our region the elm samples were dated according to the oak standard chronology. Average tree-ring curve Jivova_prum6 was elaborated from tree-ring curves of sample L6165 and L6164. Average tree-ring curve Jivova_prum5 was elaborated from tree-ring curves of sample L6155 a L6153. Average tree-ring curve Jivova_prum3 was elaborated only from tree-ring curve of sample L6156.

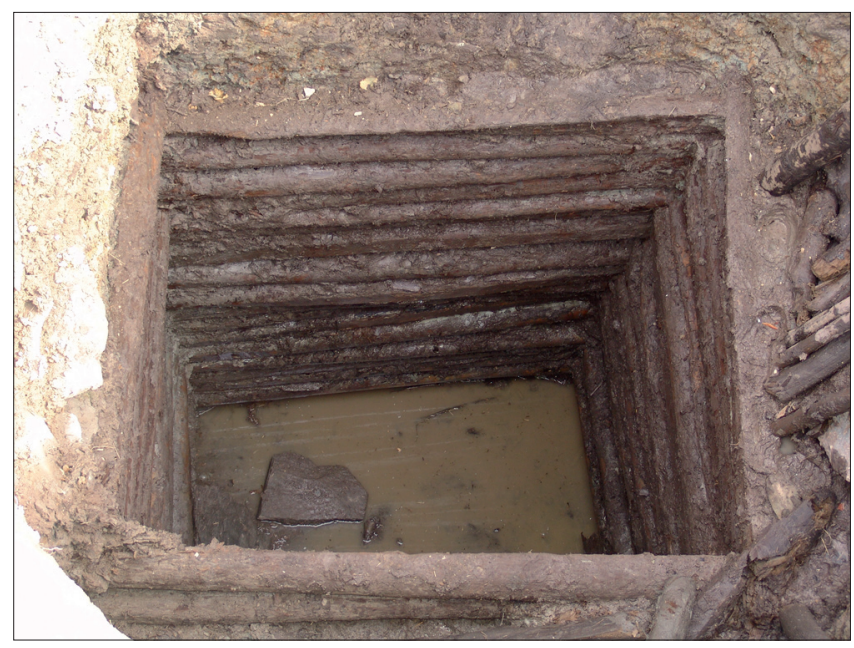

Figure 3. Jívová - Tepenec 2008. Timber casing of the cistern. Photo by V. Vranová. 


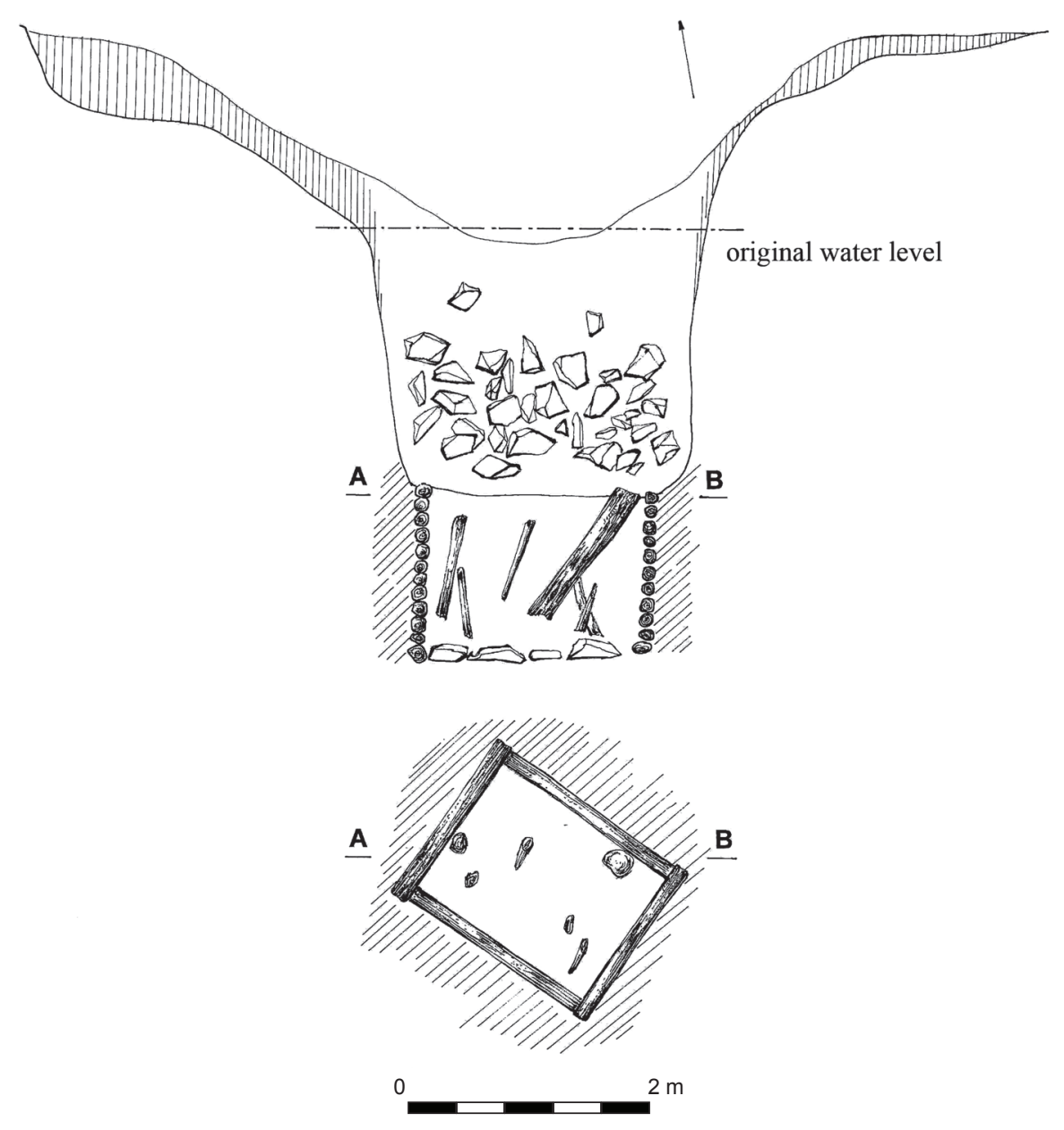

Figure 4. Jívová - Tepenec 2008. Ground plan and section of the cistern with timber casing. Picture by A. Pešková.

Table 1. Results of correlation between average tree-ring curves and standard chronologies.

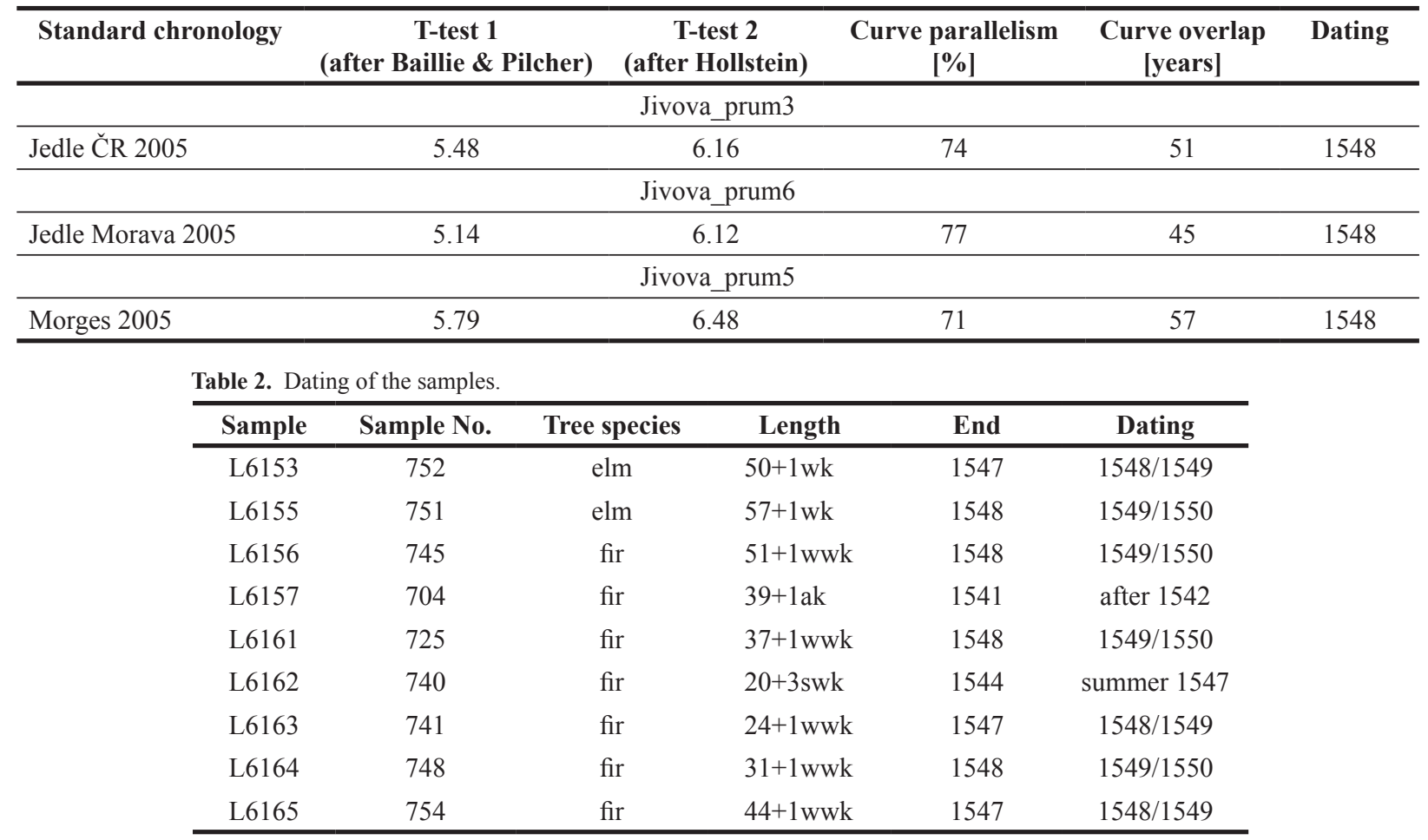


Figure 5. Synchronisation between an average tree-ring curve and the Czech fir standard chronology Jedle ČR 2005.

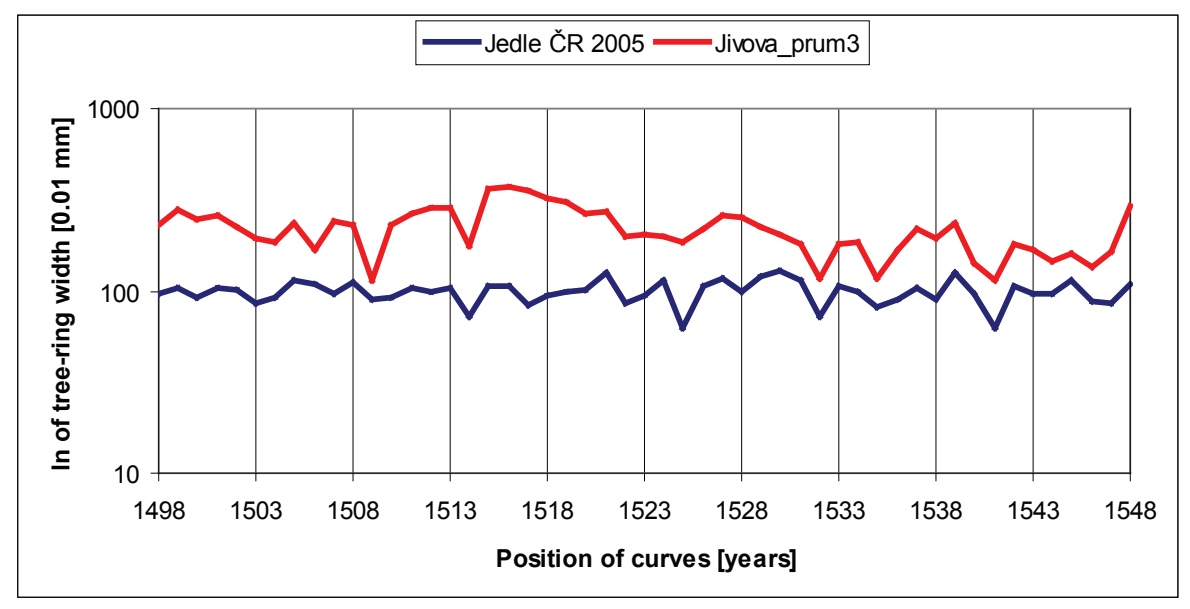

Figure 6. Synchronisation between an average tree-ring curve and the Moravian fir standard chronology Jedle Morava 2005.

Figure 7. Synchronisation between an average tree-ring curve and the Moravian oak standard chronology Morges 2005.
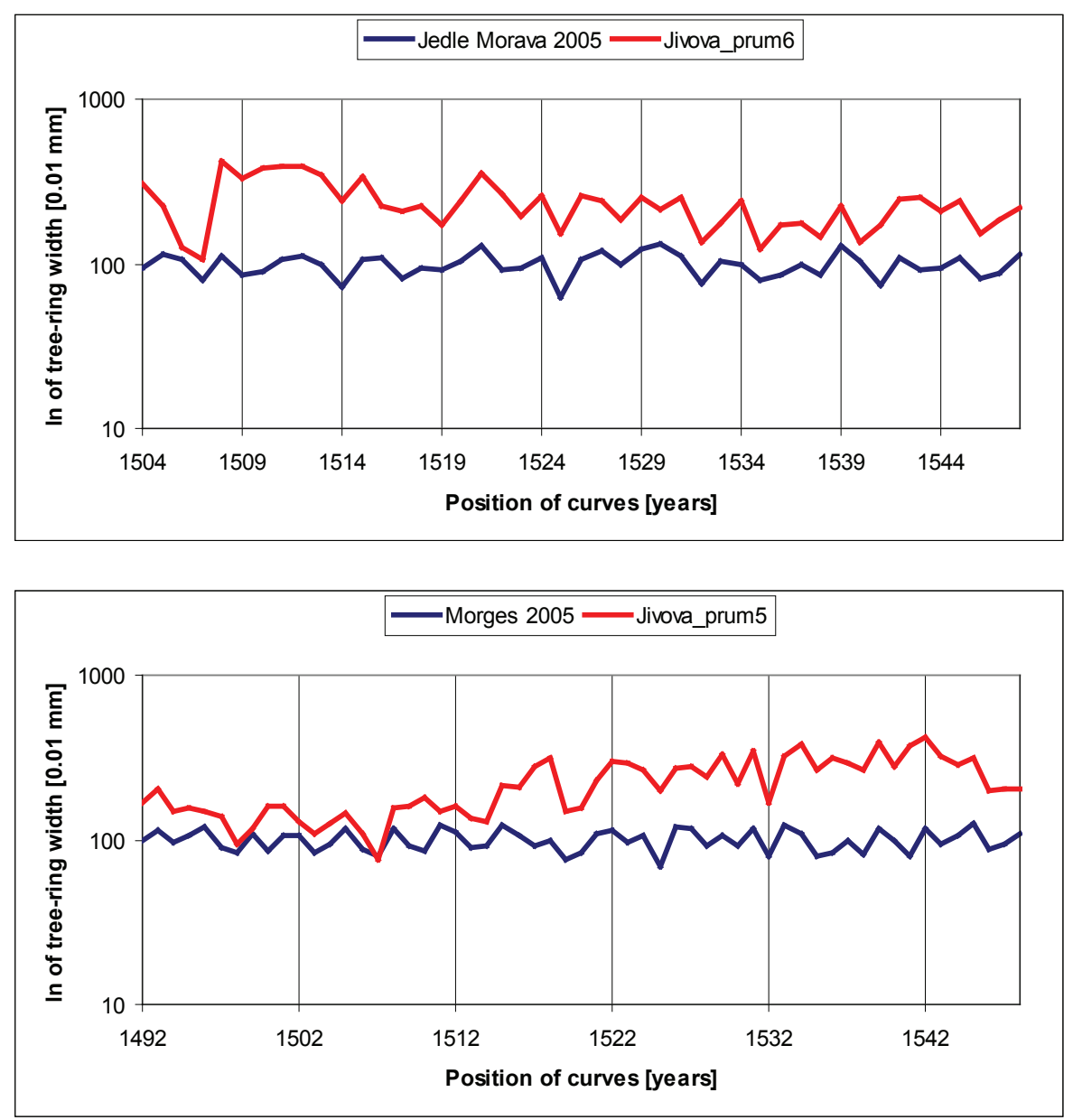

Statistical parameters of the degree of resemblance between average tree-ring curves and the standard chronologiesreached sufficiently high values for reliable dendrochronological dating. Considering the fact that the tree-ring curve to be dated and the standard chronology overlapped in forty treerings, the critical value of Student's t-distribution by the significance level of $0.1 \%$ is 3.551 (Šmelko, Wolf 1977). The values of our t-tests are higher than 3.551 (Table 1), giving evidence of the reliability of dating. The accuracy of the dating procedure is also corroborated by the agreement between standard chronologies and average tree-ring curves in most extreme values (Figures 5, 6 and 7).

The dated average tree-ring curves helped to date the treering curves of samples, from which the average tree-ring curves were elaborated. In samples containing the waney edge (wk) it was possible to determine the year in which the trees were cut down. In the sample which did not contain the waney edge (ak) it was only possible to determine the year after which the tree was cut down (Table 2). Samples Nos. 751, 752 and 754 came from the collapsed aboveground 
construction, the other samples ware taken from the timber casing of the cistern.

\section{Results}

The final dating of the timber casing of the cistern to 1548 was relatively surprising with regard to the current state of archaeological knowledge of the Tepenec site. The mid- $16^{\text {th }}$ century represents a period in which the castle was ruined, deserted and belonged to property of the Carthusian monastery in Olomouc, originally in Dolany. From the point of view of archaeology there is no distinctive settlement evidence in this locality, which would at least indicate a reason for building such a relatively intricate structure. Modern artefacts (above all ceramic fragments) can also be found in the area of the bailey, but in comparison to the amount of medieval finds it is merely a sporadic occurrence. At the present time and by the present knowledge of the site it is possible that during future excavations in the bailey we will discover evidence of early modern activities related to the building of the cistern casing. However, we consider it more probable that in this case activities might be involved which do not leave behind any distinct traces in the terrain - as for example a pastoral hut or hermitage. To resolve this question, significant help might arise from a detailed study of written sources from the Order's charterhouse in Dolany. In any case, we consider it probable that the cistern on Tepenec served the medieval castle, and the rectangular timber casing was set into its round pit as late as the following century.

\section{Conclusion}

In conclusion it should be noted that although the dendrological dating of timber from the cistern casing might have initially appeared somewhat redundant, given the short duration of the castle, it has helped to reveal new and unexpected information and thus bring us a step forward in our knowledge of the history of Tepenec Castle. From the point of view of dendrochronology the archaeological excavations represent a valuable source of dendrological material that serve to elaborate standard chronologies for Moravia and the region of our republic. The improvement of these standard chronologies is invaluable for future dendochronological research.

\section{Acknowledgements}

The article was provided with financial support under research project MSM 6215648902, grant projects GAČR 205/08/0926 and 404/08/P367, and VaV SP/2d1/93/07.

\section{References}

BURIAN, V. 1979: Tepenec - moravský hrad markraběte Karla, Umění XXVII/3, Praha, pp. 245-249.

COOK, E. R., KAIRIUKSTIS, L. A. 1990: Methods of DendrochronologyApplications in the Environmental Sciences. Kluwer Academic Publisher and International Institute for Applied Systems Analysis, Dordrecht, Boston, London, 394 pp.

KALÁBEK, M., TYMONOVÁ, M. 1998: Jívová - Tepenec, $1^{\text {st }}$ stage. Excavation report, nr. 1393/01, 1394/01, 1315/02. Deposited: Archive of the Excavation Reports, Institute of Archaeology of the Academy of Sciences of the Czech Republic, Brno.

KALÁBEK, M., TYMONOVÁ, M. 1999: Jívová - Tepenec, $2^{\text {nd }}$ stage, Excavation report, nr. 1395/01. Deposited: Archive of the Excavation Reports, Institute of Archaeology of the Academy of Sciences of the Czech Republic, Brno.

PROCHÁZKOVÁ, P. 2001: Jívová - Tepenec, 3rd stage. Excavation report, nr. 73/02. Deposited: Archive of the Excavation Reports, Institute of Archaeology of the Academy of Sciences of the Czech Republic, Brno.

RYBNÍČEK, M. 2004: Dendrochronologická analýza krovu kostela Nanebevzetí Panny Marie a Sv. Ondřeje ve Starém Hobzí, Acta univ. agric. et silvic. Mendel. Brun., 2004, LII, No. 5, pp. 155-168.

RYBNÍČEK, M., KOŇAS, P., KOLÁ̌̌, T. 2010: The Benefits of Tree-Ring Curves Detrending for Dating Archaeological Wood. Geochronometria. Vol. 35, No. 1, pp. 85-90.

ŠMELKO, Š., WOLF, J. 1977: Štatistické metódy v lesnictve. Príroda, $330 \mathrm{pp}$.

VINAŘ, J., KYNCL, J., RU゚ŽIČKA, P., ŽÁK, J. 2005: Historické krovy II. - prüzkumy a opravy, Grada, Praha, 301 pp.

VRÁNOVÁ, V. 2008: Jívová - Tepenec (okr. Olomouc), Přehled výzkumů 49, Brno, pp. 308-309, 405-406.

VRÁNOVÁ, V. 2009: Jívová (okr. Olomouc), Přehled výzkumů 50, Brno, 287, pp. 393-394.

VRÁNOVÁ, V., VRÁNA, J. 2005: Jívová - Tepenec, Pravěké hradisko a Karlův hrad - Tepenec, Archeologické památky střední Moravy, Vol. 9, Olomouc. 